Document downloaded from:

http://hdl.handle.net/10251/93267

This paper must be cited as:

Pellicer Armiñana, E.; Correa Becerra, CL.; Yepes Piqueras, V.; Alarcón, LF. (2012). Organizational improvement through standardization of the innovation process in construction firms. Engineering Management Journal. 24(2):40-53.

doi:10.1080/10429247.2012.11431935

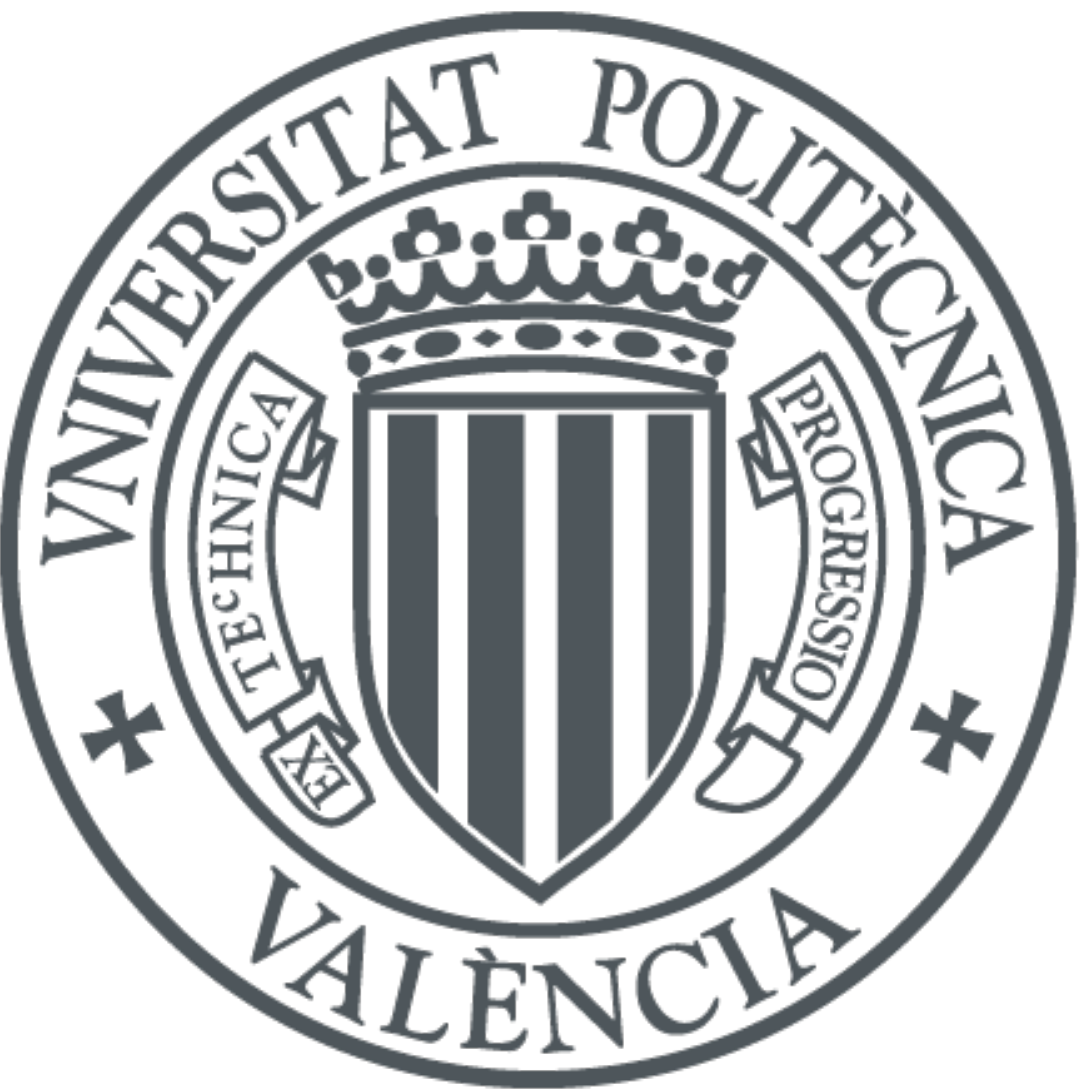

The final publication is available at

http://dx.doi.org/10.1080/10429247.2012.11431935

Copyright Taylor \& Francis

Additional Information 


\title{
ORGANIZATIONAL IMPROVEMENT THROUGH STANDARDIZATION OF THE INNOVATION PROCESS IN CONSTRUCTION FIRMS
}

\author{
Eugenio Pellicer \\ Christian L. Correa \\ Víctor Yepes \\ Luís F. Alarcón
}

\begin{abstract}
The purpose of this article is to identify the drivers, success factors, benefits and barriers to innovation in a medium size construction firm with a standardized innovation management system. The case study method is used to compare theory to reality from different perspectives, building explanations from a Spanish contractor observed over a three year period. Findings suggest that innovation management can be standardized, which leads to an organizational improvement for the company and at the same time this improvement facilitates organizational problem-solving on a regular basis, increasing technical capabilities, knowledge management, business profit and client satisfaction. The framework described in this research aims to provide guidance for managers, thus they can innovate in a systematic way. However, this exploratory study has still to be validated by empirical investigations on a larger scale through a significant number of certified companies, which is currently not yet the case in the Spanish construction industry.
\end{abstract}

KEYWORDS: competitiveness; construction; innovation; organizational improvement; standardization

\section{INTRODUCTION}

The Lisbon Strategy highlights the importance of knowledge and innovation as engines of sustainable growth in the European Union (CICYT, 2003). The objective of this strategy is to boost investment in research and development (R\&D) to 3\% of the Gross Domestic Product (GDP). However, this goal is still distant. In fact, the 27 members of the European Union (EU-27) only spent $1.77 \%$ of their GDPs on innovation in 2006. In Spain, the investment in that same year was even lower: 1.20\% of the GDP (OECD, 2008).

The European construction industry invests less in innovation than the average of the economy. In 2007, the sector employed $8.1 \%$ of the population and generated $11.3 \%$ of the GDP in the EU-27; the percentages for Spain were higher: $12.7 \%$ and $17.9 \%$, respectively (SEOPAN, 2008). The expenditure figures for R\&D in 2007 were only $0.27 \%$ of the Gross Value Added in the Spanish construction sector (COTEC, 2009), which is one eighth of the EU-15 average for 2000 (Villar-Mir, 2001). Thus, Spain, and especially its construction industry, is far behind R\&D investment in western economies.

To encourage private investment in R\&D, the Spanish government sponsored two types of incentives. First, tax benefits such as those established in Spanish Law 4/2004 on Income Tax. Second, standardization of innovation processes through the set of standards UNE 166000 (Correa et al., 2007; Pellicer et al., 2008 \& 2010). These standards, published in 2006 using the terminology and definitions of the internationally recognized Oslo Manual (OECD, 1992), address two fundamental aspects of innovation: (1) the specific design and implementation of projects via the standard UNE 166001 (AENOR, 2006a); and (2) the management within the company, considering it as a process that can be standardized following a model similar to those of quality or environmental management via the UNE 166002 standard (AENOR, 2006b). At the end of 2006, the Spanish Ministry of Infrastructure began to evaluate how contractors innovate; this Ministry gives additional points in the bidding process, raising the final score by 10-25\% (Pellicer et al., 2008 \& 2010).

With this scenario in mind, this article puts forward the following statements regarding a construction company: (1) innovation management is a process, and as such, can be standardized; (2) standardization of innovation is an organizational improvement for the company; and (3) organizational improvement increases technical capabilities, knowledge, business profits and client satisfaction. To confirm these statements, this research makes use of the case study method, considering that at the beginning of this research there was only one Spanish contractor whose innovation system was certified under the UNE 166002 standard (Pellicer et al., 2008 \& 2010). Research questions are structured so as to learn why the company innovates (the motives), which strategies are applied (the means), and what are the results (the ends). This way, the research aims to identify drivers, strategies, success factors, benefits, and barriers to innovation in medium-sized contractors. Most of these conclusions can be generalized to other project-based companies.

This paper starts with the literature review, which introduces an innovation management framework to be compared with the observed reality. Section 3 describes the research method and provides background on the selected case study organization. Our exploratory research identifies 18 propositions that respond to the research questions above, which fit the innovation management framework proposed in section 2; section 4 explains and discusses these propositions. Finally, section 5 displays the main conclusions and the managerial implications of the study. 


\section{INNOVATION MANAGEMENT FRAMEWORK}

There is no generally accepted definition of innovation at the present time (Baregheh et al., 2009). Gibbons et al. (1994) defines innovation at the level of an individual company, as "the application of ideas that are new to the firm, whether the new ideas are embodied in products, processes, services, or in work organization, management or marketing systems”. Other authors, such as Tatum (1987), West and Anderson (1996) and Wong et al. (2009) use definitions with the same basic view. Furthermore, in this same line of thought, innovation management can be seen as the generation of the suitable circumstances in an organization to carry out technological, market and organizational changes with a certain degree of uncertainty (Tidd et al., 1997).

To adequately describe the innovation system, this research includes an extensive review of the literature and feedback through interviews from experts, colleagues and professionals from the industry. The result is an innovation management model that was developed early in the research (Correa et al., 2007). Successive use of the model validated it through analyses of cases and interactions with the industry for the period of formulating and testing research propositions. The literature review informs the development of the model. In order to give proper credit to the main sources, the following brief description of the model includes the essential references that support the different elements of the model.

\subsection{Business environment}

The business environment includes factors affecting company behavior and its innovation strategy. Several studies (Pries and Janszen, 1995; Seaden et al., 2003; Sexton and Barrett, 2003) analyze the relationship between the business environment and innovation in construction companies. Relationships between stakeholders influence the integration of actors in the production process, the knowledge flow, the organization and coordination among projects, and the dissemination of innovations (Dubois and Gadde, 2002; Linton, 2000). Coordination with suppliers is also essential (Chang and Shen, 2009). The state plays a crucial role in innovation by encouraging innovation through financial support and standardization (Gann, 1997). Most contractors structure their competitiveness on a cost-based strategy (Pries and Doree, 2005). Product suppliers also contribute to innovation (Andersen et al., 2004), which implies progress in technology, processes or products that boost productivity and reduce costs. In the construction sector it is easy to copy new processes and products, thus an innovative business strategy must identify different and efficient solutions to widen the competitive gap (Manley et al., 2008).

\subsection{Organizational capabilities}

Financial, human, technological and infrastructure resources are necessary to generate new ideas. Individuals can encourage, support or cooperate in innovation through leadership (Nam and Tatum, 1997). The site manager is a key part of the organization with respect to innovation (Dulaimi et al., 2005; Park et al., 2004). The success of innovation depends on the organizational culture (Dikmen et al., 2005). Company culture that values innovation and change (Park et al., 2004) incorporates recognition and financial incentives for creativity and risk tolerance and accepts development failures and human errors. The fundamental elements for innovation are a long term perspective, the ability to generate an innovation environment, and the existence of high levels of communication (Little, 1985). According to Ling (2003), only highly motivated teams successfully undertake innovation projects.

\subsection{Innovation system}

The management of an innovation system entails all the activities required to efficiently develop a novel idea (West and Anderson, 1996). The first one of these activities is to establish a strategy that comprises the goals (ends) and the policies (means) of the organization to manage the innovation properly (Nystrom, 1979; Martensen and Dahlgaard, 1999; AENOR, 2006b). The system is completed with four other activities: planning, performing, monitoring, and assessment. These steps are similar to the well-known PDCA (plan, do, check, and act) cycle (Deming, 1994). These five activities also form a continuous loop. Eaton (2001) indicates other conditions for successful innovation processes: capacity to work with other organizations; specialization; concern for client satisfaction; and development of research capabilities. Other authors (Chang and Shen, 2009; Kangari and Miyatake, 1997; Linton, 2000) highlight the need for stakeholders to cooperate in the innovation process to maintain and improve competitiveness. Quality management creates conditions to develop, supervise and control innovation; hence, the efficiency of innovation projects is improved (Bossink, 2002; Prajogo and Sohal, 2006; Santos-Vijande and Alvarez-Gonzalez, 2007). The monitoring of technological development and its application by competitors facilitate the creation of awareness of technological trends (Sexton et al., 2006).

\subsection{Innovation sources}

The execution of an innovation project is the result of a decision-making process based on the evaluation of expected outcomes, the analysis of the firm's technological capabilities, and the study of the requirements of new technology (Mitropoulus and Tatum, 2000; Andersen et al., 2004). For contractors, innovation can mean 
adopting a new idea (Winch, 1998) or even solving a construction problem (Manseau and Shields, 2005; Tatum, 1987). Demands of clients motivate companies and individuals to innovate (Blayse and Manley, 2004; Mitropoulos and Tatum, 2000; Nam and Tatum, 1997).

\subsection{Outcomes of innovation}

In construction firms, an innovation project may involve four objectives (Nam and Tatum, 1992; Tatum, 1987; Winch, 1998): (1) improving competitiveness of the company; (2) increasing its technical capacity by being able to solve organizational problems; (3) offering incentives for employee learning; and (4) succeeding in transferring the solutions to subsequent projects. Nonetheless, the systematic exploitation of benefits requires that one individual in the company is in charge of these activities, including the protection and dissemination of results (AENOR, 2006b; Yepes et al., 2010).

\subsection{Basic model}

The innovation management system is based on open systems theory, since it is formed by a set of elements that are linked to achieve specific goals. The innovation management system works consuming inputs and producing outputs, and adapts to the environment through a feedback process, as it is shown in Exhibit 1. In our case, the drivers of the innovation are the novel ideas that emerge at the company level (organization and marketing basically) as well as the project level (production at the construction site). The results are innovation projects in addition to any other benefit that comes from the innovation system. The environment is the construction industry in which the company works, as well as the organization as a whole (the construction company). The feedback is integrated in the system itself. In fact, the system works as a continuous loop with five basic steps: defining strategy, planning, performing, monitoring, and assessment (see Exhibit 2). These steps are also required by the UNE 166002 standard (AENOR, 2006b).

$<$ EXHIBIT 1 HERE $>$

$<$ EXHIBIT 2 HERE $>$

The model displays a scheme where contractors collect novel ideas from the entire organization and transform them into projects. The success of the system depends on elaborating a strategy that focuses activities towards innovation. To design an innovation strategy, one must consider the business environment and the organizational capabilities. They are reflected in objectives and policies that facilitate communication and understanding throughout the organization. Consequently, the results of innovation projects have an impact on the company and on the construction site.

Other innovation systems for project-based industries were previously proposed by several authors. Winch (1998), for instance, builds a model around two basic concepts (company and project) and one main relationship (organizational learning). Seaden et al. (2003) propose to link the environment with business strategy, affecting the innovative capability of the organization. Sexton and Barrett (2003) define a model based on the innovation process as well as its internal and external context. The internal context includes business strategy, market positioning, work organization, technology, and human resources, while the external context includes the different business environments and their interactions. Dikmen et al. (2005) put forward a systematic innovation model with five basic elements: objectives, strategies, sources, barriers, and organizational factors. Schoen et al. (2005) describe a more ambitious model, linking innovation, as defined by Gibbons et al. (1994), with invention and basic research. Finally, Hartmann (2006) proposes a model to evaluate innovation projects based on their attractiveness and strength. In this sense, projects are attractive if they present high potential for dissemination and resolution of problems, while their strength is based on differentiation and their capacity to be implemented. Having introduced models for innovation management, the details of the study are provided next.

\section{METHOD}

The case study is a qualitative research strategy suitable for investigating a contemporary phenomenon in its true context, and specially those for which there are many more variables of interest than data (Yin, 2003). When this research started, only one Spanish contractor, whose innovation system was certified under the UNE 166002 standard (Pellicer et al., 2008 \& 2010) was available. This context justifies an exploratory investigation based on analytical induction by means of a case study. This method allows the generation of propositions (or construction of theory) that can be validated later (Eisenhardt, 1989).

To select the case study company, the construction sector was investigated to identify representative medium-sized contractors. Marti and Gonzalez (2010) described the Spanish construction industry in-depth from the point of view of its business structure. Two variables are usually used to define the size of a company in United States (SBA, 2011), as well as in the European Union (European Commission, 2004): revenues and employees. Revenues are obtained by calculating the income that the company receives during one year from its services (or sales), only for construction activities in this case, not including taxes. The number of employees quantifies the staff who work at the company during one year, taking into account part-time workers as 
fractions. Two other variables were added to complete the search: market or sub-sector inside the construction industry where the companies perform their activities based on the type of project developed; and number of regional offices with permanent staff, to provide additional insight into the geographical extension of the companies.

Summarizing, the variables analyzed were market, sales, employees, and regional offices. The study examined sixty-five construction companies, belonging to three Spanish business associations (FECOVAL, ANCI and SEOPAN) which group companies according to the aforementioned variables (eInforma, 2005). The characteristics of the virtual average company were obtained (see Exhibit 3). Three out of 65 companies were similar to these "average" characteristics. Each of these three companies was invited to participate in the research. The selected medium-sized company was the only company that agreed to participate, and to use the process as a means to achieve certification under the standard UNE 166002 (AENOR, 2006b).

The selected company has been carrying out civil and building projects in Spain since the sixties. Its revenues at the beginning of the research period were 410 million Euros, with a progressive increase in revenues over the last decade. This company is not a public business entity. Exhibit 3 summarizes the characteristics of this company compared to the virtual average company. The unit of analysis was the construction company as a whole: the central headquarters, the regional offices, and the construction sites. Each one of the regional offices was visited, at least once; whereas many construction sites of the company (more than one hundred across the three years of the study) were also examined, mainly those sites whose manager had ideas that could be implemented into innovation projects.

$<$ EXHIBIT 3 HERE $>$

The research team observed and studied the company for three years. The first year comprised an indepth analysis of the company (Pellicer et al., 2010), as well as the implementation of the innovation management system according to the UNE 166002 (Yepes et al., 2010). The last two years involved the identification of success factors, benefits and barriers to innovation, in addition to follow-up on the implementation.

The research process undertaken for this case study is that proposed by Yin (2003). The process includes six basic steps: (1) literature review; (2) design of logical model; (3) data collection; (4) data analysis; (5) results of the study; and (6) generalization of the results of the single case (or external validation). The literature review was improved throughout the investigation to refine the propositions. A model was built using multiple sources of evidence and encompassing the facts observed in a logical way; this model compared theory to reality from different perspectives and constructed explanations of the phenomena under study. Over the complete three-year research period, several methods were used to collect data. Exhibit 4 provides an overview of these methods.

$<$ EXHIBIT 4 HERE $>$

Two fundamental limitations of the case study method are investigator bias and generalization of results (Yin, 2003). The design and implementation of a protocol for research can help overcome these limitations. Internal validity is achievable, when four approaches are used: (a) using multiple sources of information; (b) linking observed facts from different perspectives; (c) comparing theory to observed reality (or patternmatching); and (d) explaining the studied phenomena (or explanation-building) using the findings through argumentation diagrams. This research utilized these approaches.

\section{RESULTS AND DISCUSSION}

The purpose of this article, as stated previously, is to analyze the outcomes of the implementation of the innovation management system in the selected construction firm, using the procedures detailed by the Spanish UNE 166002 standard. Nonetheless, a proper explanation of the changes introduced in the firm has to be set forth. These changes include the implementation of the innovation system from an operational point of view and the establishment of new functions in the organizational structure. They are described in 4.1 and 4.2 , respectively. Furthermore, quantitative data on the performance of the system during the research period are summarized in 4.3. The research outcomes are analyzed in 4.4.

\subsection{Implementation of the innovation management system}

The innovation management system forms part of the overall management system of the business. Its purpose is to introduce and maintain the company's innovation policies and to plan, perform, monitor, and assess the innovation process of the company according to its business' strategy (AENOR, 2006b). The two main shortterm goals of an innovation system are: (a) to foster an innovative spirit and creativity; and (b) to improve knowledge management in the company. To achieve these goals, an innovation process must be designed and its own organizational structure should be established. The innovation process consists of five sub-processes (AENOR, 2006; Pellicer et al., 2008 \& 2010): (1) technology watch; (2) creativity (generation of ideas); (3) planning and executing innovation projects; (4) technology transfer; and (5) protection of results. The standard UNE 166002 follows a philosophy of continuous improvement, characteristic of the ISO 9001 standard for quality management (Pellicer et al., 2008). Several authors support the idea that a proper quality management 
system improves the innovation abilities of a company (Perdomo-Ortiz et al., 2006 \& 2009). Going even a step further, Casadesus et al. (2011) propose the joint application of standardization to several management systems. These authors consider this strategy beneficial to create more synergies between these systems. In a similar way, Coelho and Matias (2010) suggest that the innovation system should be integrated with other management systems, such as quality, environment, occupational safety, or social responsibility.

The first assignment after the outlining of the innovation process was the diffusion of the system among employees and other external stakeholders (suppliers, subcontractors, and clients mainly) to start disseminating the innovation culture of the firm. Several tasks were performed in order to spread the proper information regarding the goals of the system and the implementation process: e-mails to every employee, a comprehensive report in the internal bulletin, meetings with managers (site and staff) at each one of the regional offices, as well as with workers at some of the largest construction sites, introduction of the system in the employee handbook, and even advertisements and articles in industry magazines. Further activities were developed throughout the implementation process to keep the stakeholders' interest. These activities will be discussed in more detail in the following sections.

Each innovation project had to comply with several factors established by the innovation committee: (a) affinity with the firm strategy; (b) profit (if possible) or alternative benefits; (c) applicability to other construction projects; (d) tax reduction or funding opportunities; and (e) impact on the market (if possible). Furthermore, an innovation project was not considered complete until two conditions were met: (1) it had to be actually implemented at the construction site or at the organizational level; and (2) it had to be certified by an external body.

\subsection{Organizational change}

Previous to the introduction of the innovation system, the organizational structure of the company was vertical and focused on functions. However, the organizational structure at the construction site was based on project teams. The first change, resulting from the UNE 166002 standard, was the creation of a committee to lay out the policies and monitor the implementation of the innovation system at a management level. This committee was composed of the CEO of the company, the head of the innovation department, the director of one of the regional offices, the head of the quality department, and a representative of a construction site manager.

Another important change made to the organizational structure was the creation of a specific department in charge of innovation. This department had five specific functions consistent with the five subprocesses described in section 4.1. The first function, technology watch, was carried out by a set of experts in strategic subjects defined by the innovation committee. They were coordinated and supervised by personnel from the innovation department. The generation of ideas (creativity) was encouraged through an annual workshop of experts and key managers in the company, and carried out according to Barrett's proposal (2007); most of the dissemination initiatives undertaken by the innovation department encouraged active participation of all employees. The innovation projects were developed by personnel of this department in cooperation with the champion of the idea or any other expert identified by the committee. Innovation projects at the construction site were implemented by the usual construction team, with the support of a member of the innovation department and internal or external experts, if needed. The technology transfer and protection of results functions were done entirely by personnel from the innovation department. Once a year, a one-day-conference was organized by the innovation department. At this conference, innovation projects were discussed in detail (generally by their champions) to the main stakeholders of the company: key employees, suppliers, subcontractors, clients, technological partners and universities, and external consultants. The search for certification of innovations has driven organizational change resulting from the need to use employee knowledge and skills. This change is similar to changes resulting from other management systems, such as quality (Naveh and Marcus, 2003) and environmental (Link and Naveh, 2006).

\subsection{Performance results}

During the three-year research period, the company evolved significantly. Exhibit 5 summarizes key characteristics that testify to the significant changes in the performance of the overall organization (revenues, profit before taxes, and employees with university degrees) and of the innovation department (employees working at this department and innovation projects with external certification). Two facts have to be considered in order to interpret the data properly. First, the economic crisis hit the Spanish construction industry heavily in 2008 in building construction and in 2009 in civil engineering works (BDE, 2011). The second fact is that the certification of the innovation system took place in 2008.

\section{$<$ EXHIBIT 5 HERE>}

At the beginning of the research project only one individual was working in the innovation department; whereas by the end of the research project, six people were working at this department, four of them part-time, resulting in four equivalent workers. Internal and external experts as well as other personnel such as construction managers are not included in Exhibit 5. Analyzing the data from 2007 to 2009, not including the 
first year of the research (2006) and the crisis year (2010), the personnel in the innovation department increased by 33\%. During this same period, the personnel with university degrees in the company increased by $33 \%$ also. The profit increased to six times the value of revenue.

\subsection{Key issues}

The previous sections summarized the changes introduced by the company and some quantitative performance data. The case study resulted in 18 propositions, organized according to five key issues: drivers, strategy, critical success factors, benefits, and barriers. Exhibits 6-10 summarize these propositions by issue. Each of these Exhibits is arranged in columns, presenting the following information: codification, proposition, theoretical references, and methods. The references included in Exhibits 6 to 10 provided support to formulate the propositions. While all the references support the propositions, some counter-references will also be discussed.

\subsubsection{Drivers}

Regarding the drivers of innovation, Exhibit 6 shows the three main sources of innovation: $\left(\mathrm{P}_{1}\right)$ technological problems at the construction site; $\left(\mathrm{P}_{2}\right)$ demands from clients; and $\left(\mathrm{P}_{3}\right)$ stimuli from upper management. Solving problems at the construction site basically leads to innovation in processes and products. This driver was the primary detected in the firm: almost $80 \%$ of the ideas generated came from problems at the site, and more than $60 \%$ of the innovation projects fell into this category. Some illustrative examples include the use of laser equipment to position machinery, the geometric control of complex steel pieces (Vea et al., 2010), and the construction of a deck bridge using pre-assembled girders (Yepes et al., 2008). In the first and second example, the technician responsible for geometry and surveying came up with the idea; in the last example, the site manager proposed the idea. In these three examples, the innovation project was fully supported by the responsible managers.

$<$ EXHIBIT 6 HERE $>$

Some private clients and public agencies increasingly demand sustainable and environment-friendly construction. As a consequence, contractors have to innovate to meet the demands of clients. Meeting client's needs through innovation can generate organizational or marketing innovations at the firm. Not giving the necessary attention to the innovation process when clients seek innovation can have long term negative effects. A project using modular prefabrication for schools and a resurfacing process where rigid pavement in a motorway was replaced with asphalt mixed with high rubber content binders (Gallego and Santos, 2003) are two examples undertaken in the case study organization.

Senior executives stimulated the company to pursue innovation projects to improve competitiveness. Some projects were undertaken to increase productivity. One such project was the optimization of falsework removal from concrete structures used in underground parking lots (Clemente et al., 2008), where an innovative procedure resulted in a $40 \%$ schedule reduction, as well as, approximately 300,000 Euros in tax deduction. This project was championed by one of the senior executives that was aware of the important savings that this process innovation could provide to the firm. A similar project was pursued to optimize earth retaining walls using heuristic computing methods (Ballester et al., 2011). For most of this type of innovation projects, cost reduction was the key driver to obtain upper management support. This demonstrates that the adoption of a management system certifiable under the UNE 166002 standard stimulates competitiveness. This type of innovation was encouraged by the CEO of the company and led to the company being awarded more public tenders, initiating the path to a strategy of market differentiation.

\subsubsection{Strategy}

In this particular case study, the company under analysis decided to implement the innovation system to stop the main threat of staying behind its traditional competitors (contractors of medium and large size) and to exploit the opportunity to create a competitive advantage in the market, as the Spanish Ministry of Infrastructure introduced new bidding conditions that favored innovative projects from construction firms.

The need to get certification for innovation projects drove the company to pursue a certified innovation system that would ease the generation and implementation of these projects. The firm expected to establish a solid innovation strategy based on an innovation policy established by the upper management according to the UNE 166002 standard $\left(\mathrm{P}_{4}\right)$. However, even though there was diffusion of this strategy among the various stakeholders, some managers and even department heads did not understand either the motive or the goals at the beginning of the research period. For many of them the typical client was not asking for this "fancy demand" (using the words of one of the managers). Others however, were very happy to cooperate as they understood the need for a new approach to production. Age and background were not determinants for these two opposite attitudes. As such, the innovation culture permeated the organization little by little, as demonstrated by the different survey results from managers and employees during the research period. From this perspective, our findings contradict the general assumption of many authors (Cooke and Lafferty, 1987; Van den Berg and 
Wilderom, 2004; Klein, 2011; Kumar and Balakrishnan, 2011) that assert that a favorable culture in the organization is needed prior to this kind of change initiative.

Further, the company started to seek differentiation not only through the implementation of the innovation system, but also by identifying new markets in countries recently incorporated to the European Union, such as Poland or Rumania $\left(\mathrm{P}_{5}\right)$. However, the effort required to achieve a positive differentiation is often not enough in highly competitive markets like the construction industry. Sometimes this effort only avoids staying behind other competitors. Exhibit 7 details two propositions related to the innovation strategy in the company.

\section{$<$ EXHIBIT 7 HERE $>$}

In this case study, the company still prioritizes production most of the time. When confronted with the dilemma of cost savings against other benefits that could come from innovation, the upper management of the company chooses the former. The innovation project is approved by the committee only when there is a technical problem at the site, the cost of the innovation is not too high, a profit is foreseeable, or the innovation is demanded by the client. This tendency prevents the firm from considering other innovation strategies.

\subsubsection{Critical success factors}

Exhibit 8 summarizes the most critical success factors for the implementation of an innovation strategy, which were identified from the research. First, most of the ideas generated and implemented within the case study organization sought to improve processes, both in construction work and business $\left(\mathrm{P}_{6}\right)$. Previous researchers (Winch, 1998; Taylor and Levitt, 2004) claim that innovation in construction is achieved predominantly by product improvement. Our findings align with the definition of innovation given by Gibbons et al. (1994), where $75 \%$ of the innovation ideas came from process improvements in production, organization, management or marketing. Some examples of innovation processes at the construction site are the optimization of fabrication, transport, and placement of asphalt mixes, the use of laser equipment to position machinery, the geometric control of complex steel pieces (Vea et al., 2010), and the construction of a deck bridge using pre-assembled girders (Yepes et al., 2008).

$<$ EXHIBIT 8 HERE>

The company also pursued some innovation projects in the managerial field: the installation of a computer-aided system for improved management of suppliers and subcontractors; an enhanced information flow between offices and sites using mobile devices; a lean procedure for scheduling and control of construction projects involving external stakeholders; and a computer tool for operation and maintenance of hydraulic facilities. In spite of the contractors' limited influence on product design, some examples of product innovation can also be pointed out, such as the manufacturing of artificial pieces for construction of maritime dikes; a damping element in a wastewater treatment plant to avoid the water-hammer effect; and the design and development of a special network to avoid occupational accidents.

The innovation system also establishes the need to control internal processes, mainly production and managerial ones, which constitutes a basic source for generating innovative ideas $\left(\mathrm{P}_{9}\right)$. Most of the innovation projects developed came from the detection of problems at the construction site and at the managerial level. Some projects that could be applied to several construction sites however, also showed a noticeable productivity improvement: the case of falsework removal, as explained, or the optimization of logistics of asphalt mixes resulting in a $60 \%$ time savings for trucks waiting at the asphalt mixing plant and a $20 \%$ reduction in the number of trucks needed to transport the material. Furthermore, the computer system for management of suppliers and subcontractors was fully integrated into the ERP system of the company, allowing each site manager to monitor his/her own external resources. In a similar way, a simple spreadsheet to schedule and control the production in a lean way at the construction site was made available through the intranet of the firm.

Innovation management in the construction sector must integrate other disciplines such as technology watch $\left(\mathrm{P}_{8}\right)$, as required by the standard UNE 166002. Technology watch is vital to identify the state of the art in each specific sub-field, the products offered by the suppliers, and the facilities built by the competitors. Technology watch was also useful for finding the most suitable partners or institutions for innovation. The company used experts as prospectors of the environment in their specific fields. Once an interesting discovery was made, this information was placed in a special repository (database) in the firm's intranet. Everybody in the organization knew where this new information was stored, but it was up to individuals to refer to the database. Thus, the sub-process of technology watch moved knowledge management in the company. However, in two of the annual workshops, several managers complained about the shortages and deficiencies in this still embryonic stage of knowledge management at the firm, even though they did recognize the improvements achieved. Some managers suggested that "some training was required" (using their own words). In summary, the implementation of an innovation management system improves knowledge management $\left(\mathrm{P}_{7}\right)$, which enables construction companies to integrate the information generated by stakeholders.

The UNE 166002 and ISO 9001 standards share common principles and structure. As a result, the case study findings confirm that this can facilitate the implementation of the innovation system and its integration 
with other systems $\left(\mathrm{P}_{10}\right)$. This proposition has been confirmed by many authors (Exhibit 8). Countries are standardizing innovation management, such as Portugal by means of standard NP 4457 (Teixeira et al., 2009), and Chile and Mexico, using principles and structures that are similar to the current quality and environmental standards (Coelho and Matias, 2010). In the firm under study, the system adapted many procedures from the quality management system. In order to emphasize this link, the head of the quality management department was part of the innovation committee. Further, he also acted as an internal consultant during the implementation of the system. This parallel implementation of conceptually similar systems is beneficial for the organization if both systems share the same type of procedures and forms, and use common resources. Furthermore, when common procedures, forms, and resources are used, employees may not see the new system as "another cumbersome bureaucracy", as stated by a few employees. The more straightforward the system, the better the compliance by employees.

Site managers were fundamental not only to identify new opportunities for innovation, but also for the implementation and evaluation of innovation on site $\left(\mathrm{P}_{12}\right)$. Together with the innovation department, they were the main actors of the innovation process. Most of the innovation projects that came from technical problems at the construction site were proposed by site managers or by some of their assistants. Generally they were fully supported by their department heads because these innovations generated an opportunity to reduce cost and increase productivity or made a good impression on the client.

Nevertheless, in other cases, the support of the department heads was weak because they did not rely on getting additional contracts that made the investment profitable. Examples of such cases were the development of a new asphalt mix for sport facilities or a pre-cast guiding wall for placement of docks in harbors. The innovation management also involved the site managers in the assessment of the project as well as in the dissemination of results in meetings, conferences, and workshops. It should be noticed that other authors, such as Winch (1998) and Dikmen et al. (2005), do not support this finding. In this previous research the production personnel, in general, and the site managers, in particular, contributed very little to innovation in the construction industry.

The innovation management system implies the creation of specific units to undertake the different phases of innovation: conception, development and implementation. Experts in the related disciplines need to participate in these teams. Systemized innovation enables the firm to identify those activities where the organization lacks experience, resources or the necessary technological capabilities. This way, the organization can subcontract specialists, or join with technological partners or universities to overcome their technical deficiencies. The execution of innovation projects requires multidisciplinary teams made up of in-house $\left(\mathrm{P}_{13}\right)$ and external specialists $\left(\mathrm{P}_{11}\right)$. Construction projects always work under this context. The more difficult the work, the more need for internal and external specialists. In general, innovation projects at the business level encompass high-level resources. Several times the company had to ask for advice from research centers and universities. These knowledge-oriented institutions provided an overview of the problem, as well as scientific guidance that construction companies might lack. In other circumstances, however, suppliers provided technical solutions to problems, if not the whole idea, as was the case of the artificial pieces for the construction of maritime dikes. Moreover, some sources (Barlow, 1999; Jones and Saad, 2003) claim that the lack of communication and knowledge transfer among stakeholders hinders innovation.

\subsubsection{Benefits}

Exhibit 9 displays the main benefits of innovation management. The major direct benefit is clearly the ability to solve technical problems $\left(\mathrm{P}_{14}\right)$. This proposition was fully supported, and is consistent with proposition $\mathrm{P}_{1}$ (technical problems at the site as a driver of innovation) and proposition $\mathrm{P}_{12}$ (involving the site manager in the innovation process). Innovation projects imply the generation, acquisition, absorption and implementation of new knowledge in the organization to meet objectives. In addition, transferring the results from one project to another improves knowledge management in the company, and thus its ability to deal effectively and efficiently with similar technical issues in the future. A post-mortem database of construction projects, including not only the innovation activities but also the best practices, was implemented and explained to the employees for consultation and use. This repository was located in the intranet of the firm, where every employee could use it.

$<$ EXHIBIT 9 HERE $>$

Innovation improves the image of the company and increases the company's competitiveness $\left(\mathrm{P}_{15}\right)$. Several activities helped to establish a brighter image of the company. The first one was an extensive report in a prestigious magazine explaining the goals of the company related to innovation (Gil, 2007). Since 2009, external stakeholders (suppliers, sub-contractors, external consultants and clients) were invited to an annual company one-day-conference. This way, they could not only perceive the innovation effort of the firm, but also participate in the discussions and share ideas for new projects. The head of the department of innovation also lectured at several occasions in well-regarded forums, such as professional associations and universities. Another benefit is networking with the external environment. This allows companies to identify more opportunities to innovate, discover potential technology partners and disseminate the results effectively to the 
industry. In the case study organization, this was accomplished through papers published in journals and conference proceedings (Clemente et al., 2008; Yepes et al., 2008; Vea et al., 2010; Ballester et al., 2011). A survey to suppliers and subcontractors, as well as short interviews with clients, confirmed the improvement of the innovation image of the firm. A positive differentiating factor with respect to the competition is an aspect that is increasingly valued by clients.

Finally, competitiveness is undoubtedly linked to the improvement of the results of the construction projects $\left(\mathrm{P}_{16}\right)$. Some examples of increased productivity were already discussed. Procurement of public contracts increased 7\% from 2008 to 2009; this data has to be put into the perspective of the incipient economic crisis as well as the $4 \%$ increase in revenues from that same period. Furthermore, certified projects by the UNE 166001 standard attracted tax subsidies, recovering a large proportion of the investment made and improving financial results and scores in public tendering. Tax subsidies ranged from 40.000 to 300.000 Euros per innovation project, having an average of 110.000 Euros per project. Nonetheless, one must be aware of possible failures in the certification of innovation management systems in construction firms, as it happened in the case of some quality management systems (Serpell, 2007; Kumar and Balakrishnan, 2011), maybe because the implementation of the system was merely formal, without an organizational or cultural change in the company.

\subsubsection{Barriers}

Before implementing the innovation management system, the organization centered all its efforts on production processes. The firm was not conscious of innovation and did not document or transfer new ideas. The prioritization of the production processes is a barrier to detecting innovation opportunities $\left(\mathrm{P}_{18}\right)$. In spite of the company's strategic shift towards innovation, deliberated or forced by the market circumstances, and the benefits of the implementation of the innovation system, the firm still had rigid structures focused on production. This situation prevented more thinking about innovation, its processes and work procedures, which in turn precludes the recognition of innovation opportunities. During the research period, many times a site manager or a staff technician used the expression: "if I only had enough time to think..." Their production and managerial routines prevented them from thinking on innovative opportunities, as expressed by Gann and Salter (2000) and fully supported in this case study. A simple system, with easy-to-fill, computer-based forms and shared procedures and resources with other managerial systems can result in more encouragement to employees.

If senior management does not perceive innovation as a tool for competitiveness, the system is weakened and the organization is unable to fully benefit from innovation $\left(\mathrm{P}_{17}\right)$. Before implementing the system, senior executives did not care about innovation. However, market needs moved them to consider it as a potential path to increase competitiveness. In this case study, after implementing the innovation system, the senior executives demonstrated their commitment on various fronts, such as: facilitating meetings between the company and technological centers; cooperating in the design and implementation of the innovation management system; and requesting the active participation of the entire organization. However, sometimes during the implementation process this commitment decreased because of other priorities or lack of vision. Some examples of slowing down the innovation process were provided and related to proposition $\mathrm{P}_{12}$. A proposal for more resources and budget for the innovation department made by the head of this department at the beginning of 2009 were not approved by the CEO of the firm. This might have been because of the economic crisis, but nonetheless, upper management did not cut resources or budget. Another initiative from the head of the innovation department (supported by employees) was to award new ideas and cooperation in innovation projects by means of economic incentives or prizes for excellence. Unfortunately, this did not get accepted by the upper management either. Exhibit 10 summarizes the two main barriers found during this research.

$$
<\text { EXHIBIT } 10 \text { HERE }>
$$

\subsection{Detailed model}

An innovation management model was developed to integrate the propositions generated from the research. Innovation management is a process that starts by identifying opportunities to innovate, both from the requirements of each of the stakeholders (employees, clients, suppliers, subcontractor, and environment) and the difficulties that may appear at the construction site. The best ideas are selected by upper management to be transformed into innovation projects. The department in charge of innovation organizes the resources needed, allocates the assigned resources, manages the innovation project portfolio, and implements the projects. These innovations are evaluated, improved, learned and transferred to future projects. The outcomes of innovation projects are later applied to construction sites or to the company itself. Thus, the outcomes of the implementation process with new client requirements and detailed problems at the construction site provide essential feedback for the continuous innovation cycle.

Each one of the propositions is placed within the innovation model (Exhibit 1). As a consequence, an improved and more detailed model (Exhibit 11) was generated. An innovation management system can transform the drivers or sources for innovation into outcomes or benefits. This system is influenced by the business environment and the organizational capabilities of the company. Innovation should be considered as 
another management process of a company. As any other management process, innovation can be standardized, which is, in fact, one of the objectives of the standard UNE 166002.

\section{$<$ EXHIBIT 11 HERE $>$}

This case study allowed the detailed analysis of the process of innovation management in a mediumsized construction company. The results of the process indicate: (a) how the company improved knowledge management and technological capabilities $\left(\mathrm{P}_{14}\right)$; (b) how to develop those aspects of their products most valued by customers, which can improve its competitive position in the market $\left(\mathrm{P}_{15}\right)$; and (c) how innovation projects improve economic performance $\left(\mathrm{P}_{16}\right)$.

\section{CONCLUDING REMARKS AND MANAGERIAL IMPLICATIONS}

This article proposes a system for increasing the effectiveness of innovation management in construction firms. The main issue introduced is the standardization of the innovation management system. This system interacts with the environment through inputs and outputs of information. The contractor collects ideas that are transformed into innovation projects, which have an impact on the organization in general and at the construction site in particular. The resolution of problems at the construction site is the main source of innovation, hence: (1) the project objectives are fulfilled; (2) the construction processes are improved; and (3) the score of the contractor in public tenders is raised. Through standardization of the innovation management system, an organizational improvement of the company is achieved, increasing technical capabilities, knowledge, business profits, and client satisfaction.

Even though the system does not depend on the implementation of a standard, from a practitioner point of view, the system can be used by managers to help them to formalize their innovation processes and benefits through a better understanding of the factors that affect innovation. Furthermore, the application of the innovation management system in a project-based company can improve technological capabilities and facilitates organizational problem-solving in a systematic way. The implementation of the system can enhance the generation of innovation projects, as well as the identification and assimilation of internal and external knowledge. To increase the company's competitiveness using the knowledge generated by innovation, managers should smooth information flows, not only from clients, but also within the organization. The establishment of a systematic innovation process also modifies current organizational structures within the company.

Developing a standard system for innovation does not necessarily require certification. In fact, the effectiveness of certification schemes in generating actual improvements in companies has been questioned in areas such quality management (Romero and Serpell, 2007; Kumar and Balakrishnan, 2011) highlighting some problems: inadequate support by upper management, lack of motivation, inconsistent knowledge management, flawed strategy, and excessive paperwork, among others. However, in this case, the need to certify innovation projects in order to get an additional score in public biddings in the Spanish construction industry was the lever that started the process of change in the company. Surprisingly, the standardization of innovation processes appeared before a cultural change took place in the company. The certification of the innovation processes led to changes in internal regulations and additional task procedures, which should be seen as essential components of the organizational culture. This way, top managers became increasingly aware of the important advantages of having a standardized innovation system, especially for the preservation of the internal know-how and the improvement of internal processes within the company. This issue ultimately resulted in short-term success. Additionally, the certification of innovation has led to a kind of soft matrix organization. This organizational change was driven by the need to improve the knowledge and skills of employees.

Every research has some limitations, and this project was no exception. In the first place, this was an exploratory study, meaning that this model is yet to be validated by empirical investigations on a larger scale. To do this, a significant number of certified companies are required, which is currently not the case in the Spanish construction industry.

Moreover, the benefit of achieving innovation through systematic and standardized processes should be linked to the success of enterprises creating knowledge, surpassing the highly recognized serendipitous quality of innovation. Managers may realize that innovation can no longer be a spontaneous act that solves a specific problem. They can consider innovation management as another management process subject to homogenization and systematization. Standardization of innovation sets in motion the activities needed to create innovative processes, products and services. In doing so, the company's competitiveness in the market will be improved. Systematization of innovation not only facilitates the incorporation of new ideas, but also increases the ability to acquire, develop, and use new knowledge. Many companies generate innovative products and processes. However, the main challenge for engineering managers is to carry out continuous and systematic innovation, not just directing occasional efforts or generating ideas at random. Therefore, innovation can be planned, organized, directed and controlled by engineering managers as any other business activity in a project-based company. For this purpose, the framework presented in this paper aims to provide guidance for managers that aim to innovate within their organizations in a systematic way. 


\section{ACKNOWLEDGMENTS}

The research described in this paper was partially funded by Universidad Católica del Maule (project MECESUP-UCM0205), the Spanish Ministry of Infrastructure (grant 2004-36), and the Universitat Politècnica de València (contract UPV-20050921). The authors are most grateful to Ricardo Lacort, Francisco J. Vea, and Manuel Civera for their cooperation throughout the research period. Finally, the valuable commentaries and suggestions of three anonymous reviewers improved the final version of the paper.

\section{REFERENCES}

AENOR, UNE 166001/2006. R\&D\&i Management: Requirements for R\&D\&i Projects, AENOR (2006a).

AENOR, UNE 166002/2006. R\&D\&i Management: Requirements for R\&D\&i Management Systems, AENOR (2006b).

Andersen, Poul H., Nicole Cook, and Jane Marceau, "Dynamic Innovation Strategies and Stable Networks in the Construction Industry. Implanting Solar Energy Projects in the Sydney Olympic Village,” Journal of Business Research, 57:4 (April 2004), pp. 351-360.

Ballester, Mireia, Francisco J. Vea, and Víctor Yepes, “Análisis Multivariante para la Estimación de la Contribución a la Sostenibilidad de los Forjados Reticulares," Proceedings of the 5th ACHE Conference (October 2011), Barcelona (Spain).

Baregheh, Anahita, Rowley, Jennifer, and Sally Sambrook, "Towards a Multidisciplinary Definition of Innovation,” Management Decision, 47:8 (September 2009), pp. 1323-1339.

Barlow, James, "From Craft Production to Mass Customisation. Innovation Requirements for the UK House Building Industry,” Housing Studies, 14:1 (January 1999), pp. 23-42.

Barrett, Peter, "Revaluing Construction: A Holistic Model,” Building Research \& Information 35:3 (May 2007), pp. 268-286.

BDE, “Quarterly Report on the Spanish Economy,” Bank of Spain, Economic Bulletin, January (2011), pp. 1272.

Blayse, Aletha M., and Karen Manley, "Key Influences on Construction Innovation," Construction Innovation, 4:3 (September 2004), pp. 143-154.

Bossink, Bart A.G., "The Strategic Function of Quality in the Management of Innovation,” Total Quality Management, 13:2 (March 2002), pp. 195-205.

Casadesus, Marti, Stanislav Karapetrovic, and Iñaki Heras, "Synergies in Standardized Management Systems: Some Empirical Evidence,” The TQM Journal, 23:1 (January 2011), pp. 73-86.

Chang, Andrew S., and Fang-Ying Shen, "Coordination Needs and Supply of Construction Projects," Engineering Management Journal, 21:4 (December 2009), pp. 44-57.

CICYT, The Spanish National Plan for Scientific Research Development and Technological Innovation for the Period 2004-2007. Summary, Ministerio de Educación y Ciencia (2003).

Clemente, Alejandro, Francisco J. Vea, Eugenio Pellicer, and Víctor Yepes, "Optimización del Proceso de Cimbrado Consecutivo de Forjados," Proceedings of the 4th ACHE Conference (November 2008), Valencia (Spain).

Coelho, Denis A., and Joao C.O. Matias, "An Empirical Study on Integration of the Innovation Management Systems (MS) with other MSs within Organizations,” Proceedings of ERIMA (June 2010), pp. 5-13.

Cooke, Robert A., and J. Clayton Lafferty, Organisational Culture Inventory, Human Synergistics (1987).

Correa, Christian L., Víctor Yepes, and Eugenio Pellicer, "Factores Determinantes y Propuestas para la Gestión de la Innovación en las Empresas Constructoras," Revista Ingeniería de Construcción, 22:1 (April 2007), pp. 5-14.

COTEC, Tecnología e Innovación en España. Informe COTEC 2009, Fundación COTEC para la Innovación Tecnológica (2009).

Deming, W.Edwards, The New Economics for Industry, Education, Government, MIT Press (1994).

Dikmen, Irem, M. Talat Birgonul, and S. Umut Artuk, "Integrated Framework to Investigate Value Innovations,” Journal of Management in Engineering, 21:2 (April 2005), pp. 81-89.

Dubois, Anna, and Lars E. Gadde, "The Construction Industry as a Loosely Coupled System: Implications for Productivity and Innovations," Construction Management and Economics, 20:7 (October 2002), pp. 621-632.

Dulaimi, Mohammed F., "The Challenge of Innovation in Construction," Building Research and Information, 23:2 (March 1995), pp. 106-109.

Dulaimi, Mohammed F., Madhav P. Nepal, and Moonseo S. Park, "A Hierarchical Structural Model of Assessing Innovation and Project Performance," Construction Management and Economics, 23:6 (July 2005), pp. 565-577.

Eaton, David, “A Temporal Typology for Innovation within the Construction Industry,” Construction Innovation, 1:3 (September 2001), pp. 165-179.

eInforma, “Información de Empresas,” http://www.einforma.com/ (retrieved on September 27 $7^{\text {th }}$ 2005). 
Eisenhardt, Kathleen, “Building Theories from Case Study Research,” Academy of Management Review, 14:4 (October 1989), pp. 532-550.

European Commission, The New SME Definition User Guide and Model Declaration, Office for Official Publications of the European Communities (2004).

Gallego, Juan and Luis Santos, “Asphalt Mixes using High Rubber Content Binders. Resurfacing of a Rigid Pavement on the A-7 Motorway,” Revista de Obras Publicas, 3439 (December 2003), pp. 7-26.

Gann, David M., "Should Governments Fund Construction Research?,” Building Research \& Information, 25:5 (September 1997), pp. 257- 267.

Gann, David M., and Ammon J. Salter, "Innovation in Project-Based, Service-Enhanced Firms: the Construction of Complex Products and Systems,” Research Policy, 29:7-8 (August 2000), pp. 955-972.

Gibbons, Michael, Limoges, Camille, Nowotny, Helga, and Simon Schwartzman, The New Production of Knowledge: The Dynamics of Science and Research in Contemporary Societies, Sage Publications Ltd. (1994).

Gil, Ana, “Lubasa Apuesta por la Concesiones y la I+D+I,” Revista Economía 3, 177 (July-August 2007), pp. 52-54.

Hardie, Mary P., Graham Miller, Karen J. Manley, and Steve McFallan, "Experience with the Management of Technological Innovations within the Australian Construction Industry,” Proceedings of the International Conference on Management of Engineering and Technology (August 2005), pp. 244-250.

Hartmann, Andreas M., “The Context of Innovation Management in Construction Firms,” Construction Management and Economics, 24:6 (June 2006), pp. 567-578.

Jones, Martyn, and Mohammed Saad, Managing Innovation in Construction, Thomas Telford Publishing (2003).

Kangari, Roozbeh, and Yasuyoshi Miyatake, “Developing and Managing Innovative Construction Technologies in Japan,” Journal of Construction Engineering and Management, 123:1 (March 1997), pp. 72-78.

Klein, Andrew “Corporate Culture: Its Value as a Resource for Competitive Advantage,” Journal of Business Strategy, 32:2 (March 2011), pp. 21-28.

Kornish, Laura J., and Karl T. Ulrich, “Opportunity Spaces in Innovation: Empirical Analysis of Large Sample of Ideas,” Management Science, 57:1 (January 2011), pp. 107-128.

Kumar, Durai A., and V. Balakrishnan, “A Study on ISO 9001 Quality Management System (QMS) Certifications - Reasons behind the Failure of ISO Certified Organizations”, Journal of Research in International Business and Management, 1:6 (August 2011), pp. 147-154.

Ling, Florence Y., "Managing the Implementation of Construction Innovations,” Construction Management and Economics, 21:6 (September 2003), pp. 635-649.

Link, Sharon, and Eitan Naveh, "Standardization and Discretion: Does the Environmental Standard ISO 14001 Lead to Performance Benefits?,” IEEE Transactions on Engineering Management, 53:4 (November 2006), pp. 508-519.

Linton, Jonatham D., "The Role of Relationships and Reciprocity in the Implementation of Process Innovation," Engineering Management Journal, 12:3 (September 2000), pp. 34-38.

Little, Arthur D., From Vision to Reality: Managing Innovation, Arthur D. Little Inc. (1985).

Manley, Karen, Stephen L. Kajewski, Steve McFallan, and Mike Swainston, “Assessing the Value of Different Business Strategies to Innovation by Firms in the Construction Industry," Proceedings of the $4^{\text {th }}$ IEEE International Conference on Management of Innovation and Technology (September 2008), pp. 588593.

Manseau, André, and Rob Shields, Building Tomorrow: Innovation in Construction and Engineering, Ashgate Publishing (2005).

Marimon, Frederic, and Eduard Cristobal, “A Study on ISO 9000 Certification Process: Consultant Profiles and Company Behaviour,” Managing Service Quality, 15:3 (May 2005), pp. 290-305.

Martensen Anne, and Jens J. Dahlgaard, “Integrating Business Excellence and Innovation Management: Developing Vision, Blueprint and Strategy for Innovation in Creative and Learning Organizations,” Total Quality Management, 10:4/5 (July 1999), pp. 627-635.

Marti, Rodrigo, and Julio Gonzalez, “The Strategic Repositioning of Spanish Construction Companies,” Informes de la Construcción, 62:520 (October/December 2010), pp. 67-84.

Mitropoulos, Panagiotis, and Clyde B. Tatum, "Forces Driving Adaptation of New Information Technologies," Journal of Construction Engineering and Management, 126;5 (September 2000), pp. 340-348.

Nam, Chung H., and Clyde B. Tatum, "Leaders and Champions for Construction Innovation," Construction Management and Economics, 15:3 (May 1997), pp. 259-270.

Nam, Chung H., and Clyde B. Tatum, "Strategies for Technology Push: Lessons from Construction Innovations,” Journal of Construction Engineering and Management, 118:3 (September 1992), pp. 507-524. 
Naveh, Eitan, and Alfred A. Marcus, "When Does the ISO 9000 Quality Assurance Standard Lead to Performance Improvement? Assimilation and Going Beyond,” IEEE Transactions on Engineering Management, 51:3 (August 2004), pp. 352-363.

Nyström, Harry, Creativity and Innovation, John Wiley \& Sons (1979).

OECD, Main Science \& Technology Indicators. Volume 2008/2, Organization for Economic Co-operation and Development (2008).

OECD, Proposed Guidelines for Collecting and Interpreting Technological Innovation Data - Oslo Manual, Organization for Economic Co-operation and Development (1992).

Parikh, Mihir, “Knowledge Management Framework for High-Tech Research and Development,” Engineering Management Journal, 13:3 (September 2001), pp. 27-33.

Park, Moonseo S., Madhav P. Nepal, and Mohammed F. Dulaimi, "Dynamic Modelling for Construction Innovation,” Journal of Management in Engineering, 20:4 (October 2004), pp. 171-177.

Pellicer, Eugenio, Víctor Yepes, and Ronald J. Rojas, "Innovation and Competitiveness in Construction Companies: A Case Study,” Journal of Management Research, 10:2 (August 2010), pp. 103-115.

Pellicer, Eugenio, Víctor Yepes, Christian L. Correa, and Germán Martínez, “Enhancing R\&D\&i through Standardization and Certification: The Case of the Spanish Construction Industry,” Revista Ingeniería de Construcción, 23:2 (August 2008), pp. 112-119.

Perdomo-Ortiz, Jesus, Javier Gonzalez-Benito, and Jesus Galende, “Total Quality Management as a Forerunner of Business Innovation Capability” Technovation, 26:10 (October 2006), pp. 1170-1185.

Perdomo-Ortiz, Jesus, Javier Gonzalez-Benito, and Jesus Galende, “The Intervening Effect of Business Innovation Capability on the Relationship between Total Quality Management and Technological Innovation,” International Journal of Production Research, 47:18 (September 2009), pp. 5087-5107.

Prajogo, Daniel I., and Amrik S. Sohal, "The Integration of TQM and Technology/R\&D Management in Determining Quality and Innovation Performance,” Omega, 34:3 (June 2006), pp. 296-312.

Pries, Frens, and Andre G. Doree, “A Century of Innovation in the Dutch Construction Industry,” Construction Management and Economics, 23:6 (July 2005), pp. 561-564.

Pries, Frens, and Felix Janszen, "Innovation in the Construction Industry: The Dominant Role of the Environment,” Construction Management and Economics, 13:1 (January 1995), pp. 43-51.

Romero, Tania, and Alfredo Serpell, "Evaluating the Attainment of Quality Management Principles in Construction Companies Certified by ISO 9001:2000”, Revista Ingeniería de Construcción, 22:3 (December 2007), pp. 197-213.

Santos-Vijande, M. Leticia, and Luis I. Alvarez-Gonzalez, "Innovativeness and Organizational Innovation in Total Quality Oriented Firms: The Moderating Role of Market Turbulence,” Technovation, 27:9 (September 2007), pp. 514-532.

SBA, “Size Standards Methodology White Paper,” U.S. Small Business Administration, http://www.sba.gov/content/size-standards-methodology (retrieved on March $26^{\text {th }} 2011$ ).

Schoen, Jeremy, Thomas W. Mason, William A. Kline, and Robert M. Bunch, “The Innovation Cycle: A New Model and Case Study for the Invention to Innovation Process,” Engineering Management Journal, 17:3 (September 2005), pp. 3-10.

Seaden, George, Michael Goulla, Jerome A. Douxtriaux, and John Nash, "Strategic Decisions and Innovation in Construction Firms,” Construction Management and Economics, 21:6 (September 2003), pp. 603-612.

SEOPAN, Spanish Construction Activity Report 2007, SEOPAN (2008).

Sexton, Martin, and Peter Barrett, “A Literature Synthesis of Innovation in Small Construction Firms: Insights, Ambiguities and Questions,” Construction Management and Economics, 21:6 (September 2003): 613622.

Sexton, Martin, Peter Barrett, and Ghassan F. Aouad, "Motivating Small Construction Companies to Adopt New Technology,” Building Research \& Information, 34:1 (January 2006), pp. 11-22.

Slaughter, Sarah, "Implementation of Construction Innovations," Building Research and Information, 28:1 (January 2000), pp. 2-17.

Slaughter, Sarah, "Innovation and Learning during Implementation: A Comparison of User and Manufacturer Innovations,” Research Policy, 22:1 (September 1993), pp. 81-95.

Stewart, Ian, and Peter Fenn, "Strategy: The Motivation for Innovation," Construction Innovation, 6:3 (September 2006), pp. 173-185.

Tatum, Clyde B., "Potential Mechanisms for Construction Innovation,” Journal of Construction Engineering Management, 112:2 (June 1986), pp. 178-191.

Tatum, Clyde B., "Process of Innovation in Construction Firms,” Journal of Construction Engineering and Management, 113:4 (December 1987), pp. 648-663.

Taylor, John E., and Raymond E. Levitt, "Understanding and Managing Innovations in Project-Based Industries,” in Dennis P. Slevin, David I. Cleland, and Jeffrey K. Pinto (eds.), Innovations - Project Management Research 2004, Project Management Institute (2004). 
Teixeira, José C., Eugenio Pellicer, Paulo Pedro, and Víctor Yepes, “Fostering Research, Development and Innovation in Construction Companies,” Proceedings of the CIB Joint International Symposium Construction Facing Worldwide Challenges (September 2009), Dubrovnik (Croatia).

Tidd, Joe, Bessant, John, and Keith Pavitt, Managing Innovation: Integrating Technological, Market and Organizational Change, John Wiley \& Sons (1997).

Van de Ven, Andrew H., and Poole Marshall Scott, "Alternative Approaches for Studying Organizational Change,” Organization Studies, 26:9 (September 2005), pp. 1377-1404.

Van den Berg, Peter T., and Celeste P.M. Wilderom, “Defining, Measuring, and Comparing Organizational Cultures,” Applied Psychology, 53:4 (October 2004), pp. 570-582.

Vea, Francisco J., Juan Pérez, Eugenio Pellicer, and Víctor Yepes, "Sistema de Control Dimensional y de Replanteo de Alta Precisión de Elementos Prefabricados Singulares,” Revista de la Construcción, 9:2 (December 2010), pp. 116-125.

Villar-Mir, Juan M., “R\&D\&i in the Construction Sector,” Revista de Obras Públicas, 148:3409 (April 2001), pp. 7-29.

Wagner, Stephan M., “A Firm’s Responses to Deficient Suppliers and Competitive Advantage,” Journal of Business Research, 59:6 (June 2006), pp. 686-695.

West, Michael A., and Neil R. Anderson, “Innovation in Top Management Teams,” Journal of Applied Psychology, 81:6 (December 1996), pp. 680-93.

Winch, Grahan M., "Zephyrs of Creative Destruction: Understanding the Management of Innovation in Construction,” Building Research \& Information, $26: 5$ (September 1998), pp. 268-279.

Wong, Alfred, Tjosvold, Dean, and Chunhong Liu, "Innovation by Teams in Shanghai, China: Cooperative Goals for Group Confidence and Persistence”. British Journal of Management, 20:2 (June 2009), pp. 238-251.

Yepes, Víctor, Eugenio Pellicer, Christian L. Correa, Luis F. Alarcon, “Implementing a System for Achieving Innovation Opportunities in a Construction Company,” Proceedings of the CIB World Congress Building a Better World (May 2010), Salford Quays (United Kingdom).

Yepes, Víctor, Francisco J. Vea, and Eugenio Pellicer, "Certificación de la Innovación en Puentes de Vigas Preensambladas,” Proceedings of the 4th ACHE Conference (November 2008), Valencia (Spain).

Yin, Robert K., Case Study Research: Design and Methods, Sage Publications (2003). 


\section{ABOUT THE AUTHORS}

Eugenio Pellicer received his M.Sc. degree from Stanford University, USA, and his Ph.D. degree from the Universitat Politècnica de València, Spain, where he is currently working as an associate professor in project management, and he is also in charge of the M.Sc. in Planning and Management in Civil Engineering. His research interests include management of SMEs in the construction industry and their interaction with project management, innovation in the construction process, and occupational safety and health in construction. He is currently involved in several international projects with other European and Latin-American universities.

Christian Luis Correa was awarded his B.Sc. degree by the Pontificia Universidad Católica de Chile, and his M.Sc. and Ph.D. degrees by the Universitat Politècnica de València. He is currently an assistant professor of construction management at the Universidad Católica del Maule, Chile, where he lectures. He also provides advice to institutions and companies for infrastructure recovery following the devastating 2010 earthquake. His main research topic is innovation management applied to the construction industry.

Víctor Yepes is an associate professor at the Universitat Politècnica de València, where he got his Ph.D. degree. He is an expert on quality and innovation management, heuristic optimization techniques and data mining applied to construction. He is currently teaching graduate and postgraduate courses in construction engineering, innovation management as well as quality management. He is also the academic director of the M.Sc. in Concrete Engineering at the Department of Construction Engineering. He is currently the main researcher of the HORSOST project (efficient design of non-conventional concrete structures based on multiobjective sustainable criteria using data mining methods).

Luis Fernando Alarcón is the current director of the Department of Construction Engineering and Management as well as the M.Sc. in Construction Management and the Center for Excellence in Production Management at the Pontificia Universidad Católica de Chile where he is currently lecturing as professor. He obtained his M.Sc., M.Eng. and Ph.D. degrees at UC Berkeley. In 2008, he was nominated as Shimizu Visiting Professor at Stanford University. His activity as a consultant includes the US State Department, the Panama Channel, and universities including Reading and Salford in United Kingdom. His main research interest areas are production management and lean construction.

Contact: Eugenio Pellicer, School of Civil Engineering, Universitat Politècnica de València, Camino de Vera s/n, 46022 Valencia, Spain; phone: 34-963-879-562; fax: 34-963-877-560; pellicer@upv.es 


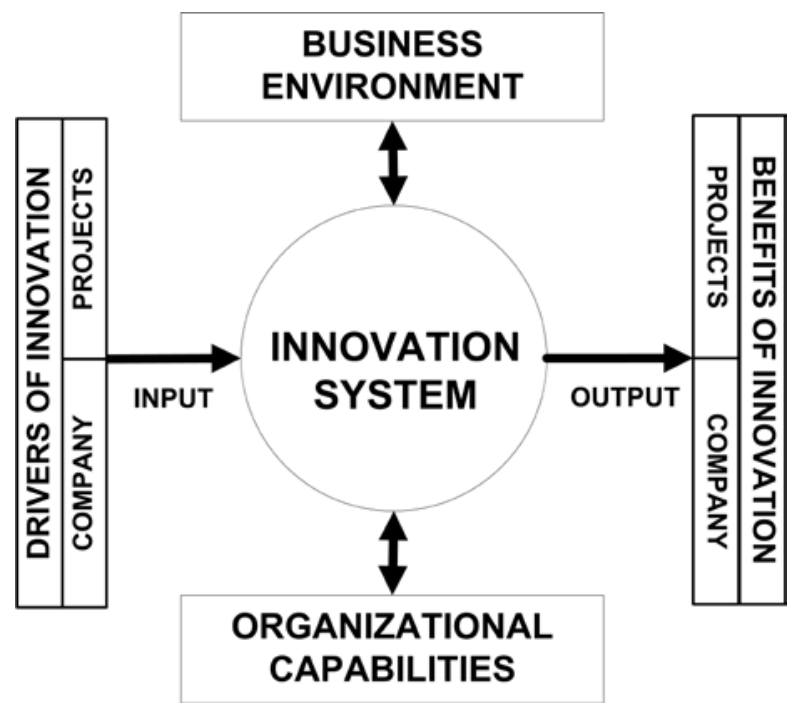

Exhibit 1. Innovation management model

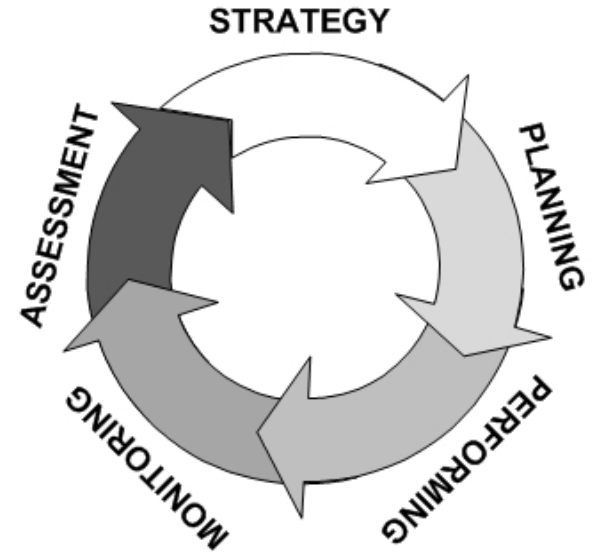

Exhibit 2. Innovation system

\begin{tabular}{lcccc}
\hline \multicolumn{1}{c}{ Company } & Type of Business & \multicolumn{2}{c}{ Average Figures } \\
\cline { 3 - 5 } & & $\begin{array}{c}\text { Revenues } \\
\text { (millions of Euros) }\end{array}$ & No. Employees No. Offices \\
\hline $\begin{array}{l}\text { Representative medium-sized construction } \\
\text { company (average of 65 cases) }\end{array}$ & Building and Civil Engineering & 358 & 434 & 8 \\
$\begin{array}{l}\text { Case study } \\
\text { Building and Civil Engineering }\end{array}$ & 410 & 360 & 8 \\
\hline
\end{tabular}

Exhibit 3. Comparison of an average company and the case study company (data from 2005) 


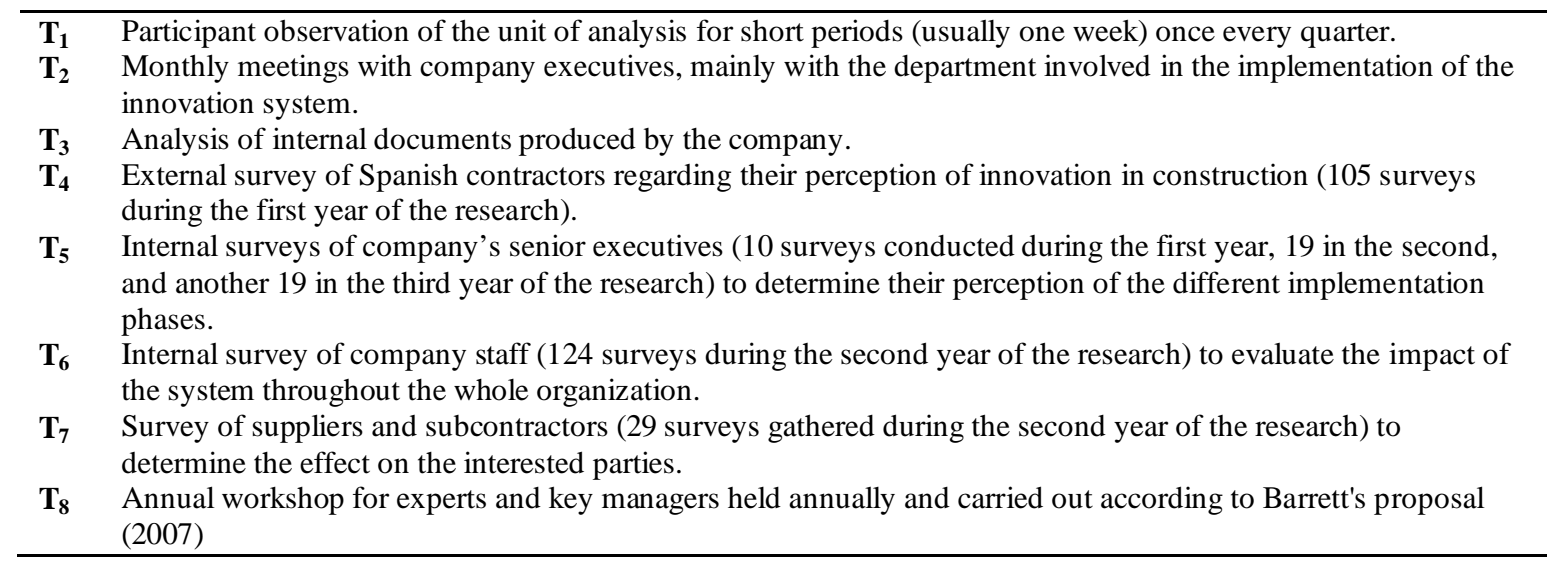

Exhibit 4. Data collection methods

\begin{tabular}{|c|c|c|c|c|c|c|}
\hline Indicator (data from $31^{\text {st }}$ of December) & 2006 & 2007 & 2008 & 2009 & 2010 & $\begin{array}{l}\text { \% Change } \\
2009 / 2007\end{array}$ \\
\hline Revenues (in millions of Euros) & 451.3 & 488.1 & 567.6 & 591.2 & 475.6 & $21 \%$ \\
\hline Profit before taxes (in millions of Euros) & 6.7 & 8.2 & 15.4 & 17.9 & 12.2 & $118 \%$ \\
\hline Employees with university degrees & 37 & 42 & 53 & 56 & 48 & $33 \%$ \\
\hline Employees working in the innovation department & 1 & 3 & 4 & 4 & 4 & $33 \%$ \\
\hline Innovation projects with external certification (per year) & 0 & 1 & 1 & 6 & 11 & $500 \%$ \\
\hline
\end{tabular}

Exhibit 5. Innovation indicators (2006-2010)

\begin{tabular}{|c|c|c|c|}
\hline Code & Proposition & References & Methods \\
\hline$\overline{P_{1}}$ & $\begin{array}{l}\text { Innovation comes from technical problems } \\
\text { that arise in project execution at the } \\
\text { construction site }\end{array}$ & $\begin{array}{l}\text { Slaughter (1993), Nam and Tatum } \\
\text { (1997), Winch (1998) }\end{array}$ & $\mathrm{T}_{1}-\mathrm{T}_{2}-\mathrm{T}_{3}-\mathrm{T}_{8}$ \\
\hline $\mathbf{P}_{2}$ & $\begin{array}{l}\text { Construction companies innovate to meet } \\
\text { client requirements }\end{array}$ & $\begin{array}{l}\text { Nam and Tatum (1997), } \\
\text { Mitropoulus and Tatum (2000), } \\
\text { Blayse and Manley (2004) }\end{array}$ & $\begin{array}{l}\mathrm{T}_{1}-\mathrm{T}_{2}-\mathrm{T}_{3}-\mathrm{T}_{4} \\
\mathrm{~T}_{5}-\mathrm{T}_{8}\end{array}$ \\
\hline $\mathbf{P}_{3}$ & $\begin{array}{l}\text { Senior management propels innovation } \\
\text { projects to improve the competitiveness of } \\
\text { the company }\end{array}$ & $\begin{array}{l}\text { Tatum (1987), Winch (1998), } \\
\text { Slaughter (2000) }\end{array}$ & $\begin{array}{l}\mathrm{T}_{1}-\mathrm{T}_{2}-\mathrm{T}_{3}-\mathrm{T}_{5} \\
\mathrm{~T}_{8}\end{array}$ \\
\hline
\end{tabular}

Exhibit 6. Drivers for innovation: propositions, references, and methods

\begin{tabular}{llll}
\hline Code & Proposition & References & Methods \\
\hline $\mathbf{P}_{4}$ & $\begin{array}{l}\text { By adopting an innovation management } \\
\text { system, innovation follows a previously } \\
\text { defined strategy }\end{array}$ & $\begin{array}{l}\text { Gann and Salter (2000), Seaden et } \\
\text { al. (2003), Stewart and Fenn (2006) }\end{array}$ & $\mathrm{T}_{1}-\mathrm{T}_{2}-\mathrm{T}_{3}-\mathrm{T}_{4}$ \\
$\mathbf{P}_{5}$ & $\begin{array}{l}\text { By implementing an innovation management } \\
\text { system, the company responds to the need to } \\
\text { generate positive differentiation that is } \\
\text { valued by clients }\end{array}$ & $\begin{array}{l}\text { Slaughter (2000), Sexton and } \\
\text { Barrett (2003), Van den Ven and } \\
\text { Poole (2005) }\end{array}$ & $\mathrm{T}_{1}-\mathrm{T}_{2}-\mathrm{T}_{3}-\mathrm{T}_{5}-$ \\
$\mathrm{T}_{6}-\mathrm{T}_{8}$ \\
\end{tabular}

Exhibit 7. Strategy of innovation: propositions, references, tools, and methods 


\begin{tabular}{|c|c|c|c|}
\hline Code & Proposition & References & Methods \\
\hline $\mathbf{P}_{6}$ & $\begin{array}{l}\text { Construction companies generally innovate } \\
\text { in processes }\end{array}$ & $\begin{array}{l}\text { Gann and Salter (2000), Sexton and } \\
\text { Barrett (2003) }\end{array}$ & $\begin{array}{l}T_{1}-T_{2}-T_{3}-T_{5} \\
T_{8}\end{array}$ \\
\hline $\mathbf{P}_{7}$ & $\begin{array}{l}\text { The implementation of an innovation } \\
\text { management system improves knowledge } \\
\text { management }\end{array}$ & $\begin{array}{l}\text { Winch (1998), Parikh (2001), } \\
\text { Hardie et al. (2005) }\end{array}$ & $\begin{array}{l}\mathrm{T}_{1}-\mathrm{T}_{2}-\mathrm{T}_{3}-\mathrm{T}_{4} \\
\mathrm{~T}_{5}-\mathrm{T}_{8}\end{array}$ \\
\hline $\mathbf{P}_{8}$ & $\begin{array}{l}\text { Construction companies that adopt an } \\
\text { innovation management system understand } \\
\text { their environment better }\end{array}$ & $\begin{array}{l}\text { Tatum (1987), Pries and Janszen } \\
\text { (1995), Seaden et al. (2003) }\end{array}$ & $\begin{array}{l}\mathrm{T}_{1}-\mathrm{T}_{2}-\mathrm{T}_{3}-\mathrm{T}_{4} \\
\mathrm{~T}_{5}\end{array}$ \\
\hline $\mathbf{P}_{9}$ & $\begin{array}{l}\text { The control of internal processes (mainly } \\
\text { production and management) constitutes a } \\
\text { basic source for generating innovative ideas }\end{array}$ & $\begin{array}{l}\text { Dulaimi (1995), Stewart and Fenn } \\
\text { (2006), Kornish and Ulrich (2011) }\end{array}$ & $\begin{array}{l}\mathrm{T}_{1}-\mathrm{T}_{2}-\mathrm{T}_{3}-\mathrm{T}_{5} \\
\mathrm{~T}_{8}\end{array}$ \\
\hline $\mathbf{P}_{10}$ & $\begin{array}{l}\text { The existence of a quality system certified by } \\
\text { the ISO } 9001 \text { standard facilitates the } \\
\text { implementation of an innovation } \\
\text { management system }\end{array}$ & $\begin{array}{l}\text { Prajodo and Sohal (2006), Santos- } \\
\text { Vijande and Alvarez-Gonzalez } \\
\text { (2007), Casadesus et al. (2011) }\end{array}$ & $\mathrm{T}_{1}-\mathrm{T}_{2}-\mathrm{T}_{3}-\mathrm{T}_{4}$ \\
\hline$P_{11}$ & $\begin{array}{l}\text { The existence of an innovation management } \\
\text { system stimulates subcontracting to } \\
\text { specialized companies and adds value to the } \\
\text { innovation process }\end{array}$ & $\begin{array}{l}\text { Blayse and Manley (2004), Wagner } \\
\text { (2006) }\end{array}$ & $\begin{array}{l}\mathrm{T}_{1}-\mathrm{T}_{2}-\mathrm{T}_{3}-\mathrm{T}_{4} \\
\mathrm{~T}_{7}\end{array}$ \\
\hline $\mathbf{P}_{12}$ & $\begin{array}{l}\text { The active involvement of the site manager } \\
\text { in the innovation process has a significant } \\
\text { impact on the results of innovation }\end{array}$ & $\begin{array}{l}\text { Park et al. (2004), Dulaimi et al. } \\
\text { (2005) }\end{array}$ & $\mathrm{T}_{1}-\mathrm{T}_{2}-\mathrm{T}_{3}-\mathrm{T}_{8}$ \\
\hline $\mathbf{P}_{13}$ & $\begin{array}{l}\text { Innovation in construction requires the } \\
\text { participation of multidisciplinary teams }\end{array}$ & $\begin{array}{l}\text { Gann and Salter (2000), Bossink } \\
\text { (2004) }\end{array}$ & $\mathrm{T}_{1}-\mathrm{T}_{2}-\mathrm{T}_{3}-\mathrm{T}_{7}$ \\
\hline
\end{tabular}

Exhibit 8. Critical success factors: propositions, references, and methods

\begin{tabular}{|c|c|c|c|}
\hline Code & Proposition & References & Methods \\
\hline $\mathbf{P}_{14}$ & $\begin{array}{l}\text { The adoption of an innovation management } \\
\text { system improves the company's } \\
\text { technological capabilities }\end{array}$ & $\begin{array}{l}\text { Tatum (1987), Nam and Tatum } \\
\text { (1992), Slaughter (2000) }\end{array}$ & $\mathrm{T}_{1}-\mathrm{T}_{2}-\mathrm{T}_{3}-\mathrm{T}_{5}$ \\
\hline $\mathbf{P}_{15}$ & $\begin{array}{l}\text { The adoption of an innovation management } \\
\text { system improves the company's } \\
\text { competitiveness }\end{array}$ & $\begin{array}{l}\text { Tatum (1987), Nam and Tatum } \\
\text { (1992), Mitropoulus and Tatum } \\
\text { (2000) }\end{array}$ & $\begin{array}{l}\mathrm{T}_{1}-\mathrm{T}_{2}-\mathrm{T}_{3}-\mathrm{T}_{5}- \\
\mathrm{T}_{6}-\mathrm{T}_{8}\end{array}$ \\
\hline $\mathbf{P}_{16}$ & $\begin{array}{l}\text { The certification of an innovation project } \\
\text { improves the results of construction projects }\end{array}$ & $\begin{array}{l}\text { Marimon and Cristobal (2005), } \\
\text { Coelho and Matias (2010), Vea et } \\
\text { al. (2010) }\end{array}$ & $\begin{array}{l}\mathrm{T}_{1}-\mathrm{T}_{2}-\mathrm{T}_{3}-\mathrm{T}_{5}- \\
\mathrm{T}_{8}\end{array}$ \\
\hline
\end{tabular}

Exhibit 9. Benefits of innovation: propositions, references, tools, and methods

\begin{tabular}{|c|c|c|c|}
\hline Code & Proposition & References & Methods \\
\hline $\mathbf{P}_{17}$ & $\begin{array}{l}\text { Innovation in construction is delayed when } \\
\text { senior management does not perceive it as a } \\
\text { competitive strategy }\end{array}$ & $\begin{array}{l}\text { Nam and Tatum (1997), Slaughter } \\
\text { (2000), Blayse and Manley (2004) }\end{array}$ & $\mathrm{T}_{1}-\mathrm{T}_{2}-\mathrm{T}_{3}-\mathrm{T}_{5}$ \\
\hline $\mathbf{P}_{18}$ & $\begin{array}{l}\text { The prioritization of production processes } \\
\text { hinders the identification of innovation } \\
\text { opportunities }\end{array}$ & $\begin{array}{l}\text { Tatum (1986), Pries and Janszen } \\
\text { (1995), Gann and Salter (2000) }\end{array}$ & $\begin{array}{l}\mathrm{T}_{1}-\mathrm{T}_{2}-\mathrm{T}_{3^{-}}-\mathrm{T}_{5^{-}} \\
\mathrm{T}_{8}\end{array}$ \\
\hline
\end{tabular}

Exhibit 10. Barriers to innovation: propositions, references, tools, and methods 


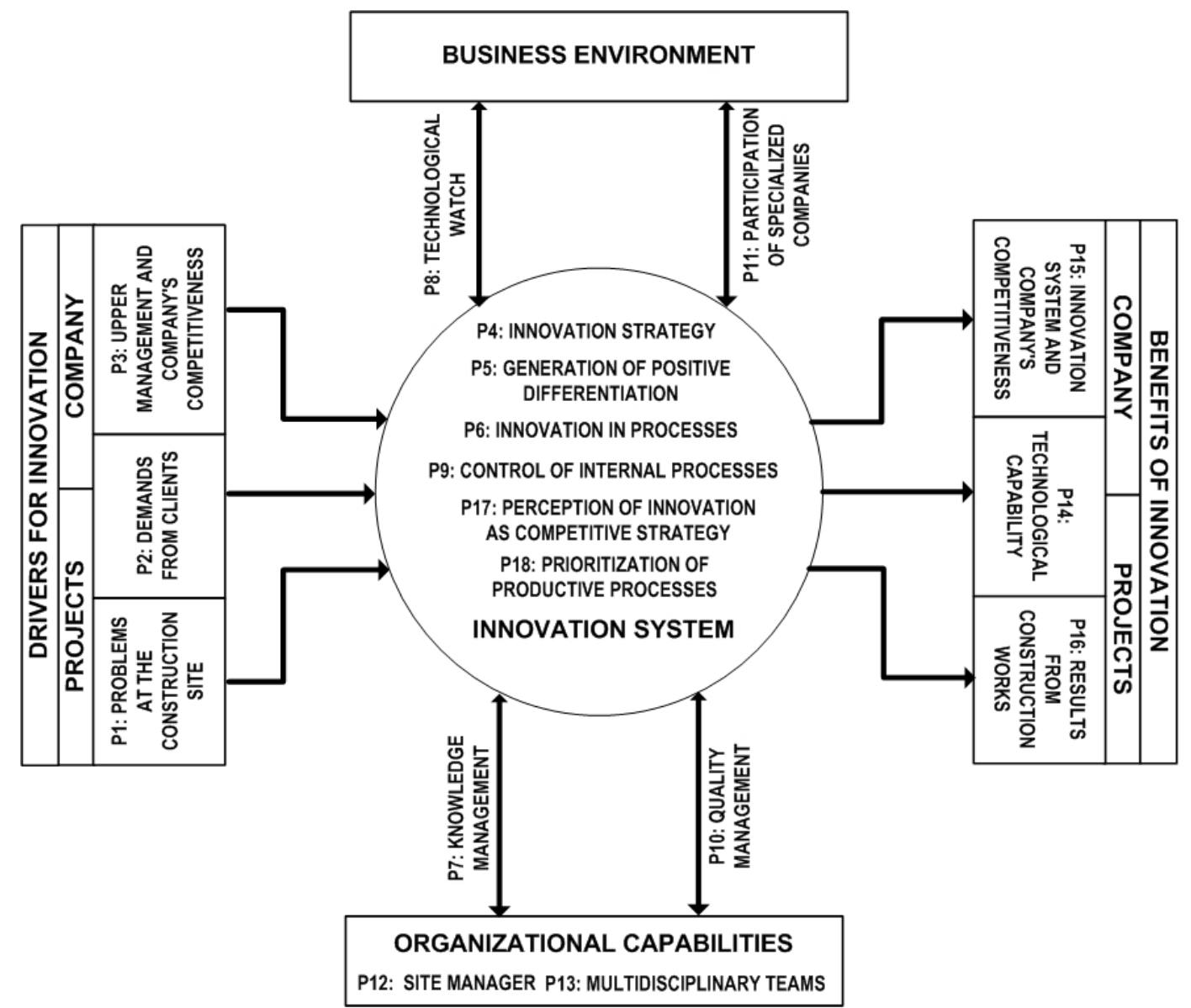

Exhibit 11. Propositions within the innovation management model 